\title{
Geomorphic characteristics of small seeps and fens in a glaciated landscape
}

\author{
Joseph W. Dixon \\ Natural Resources Conservation Service, United States Department of Agriculture, Iowa City, Iowa, USA, \\ e-mail: joe.dixon@ia.usda.gov
}

\begin{abstract}
Stratigraphic slope wetlands result from discharging ground water and can be found anywhere in dissected landscapes. Both seeps and fens are stratigraphic slope wetlands and the difference between the two in the Midwestern USA is not always clearly defined. Geomorphic features of 30 stratigraphic slope wetlands in Muscatine County, Iowa were measured using global positioning system and geographic information system technology. One-way ANOVA was used to test the hypotheses that the area, elevation, and/or slope would be significantly different between seeps and fens of differing parent material. The results suggest that fens and seeps are geomorphically indistinguishable from one another.
\end{abstract}

Key words: peatland, slope wetland, isolated wetland, Iowa, Midwestern USA

\section{Introduction}

In the broadest sense, wetlands can be defined as ecosystems that occur at the boundary between aquatic and terrestrial environments (Cowardin et al. 1979, Keddy 2010). As a result, they are typically regarded as features of flat or lowland topography (Mitsch and Gosselink 2000, Zedler and Kercher 2005, Kolka and Thompson 2012). However, wetlands can occur on slopes and slope wetlands are a common component of many landscapes (Winter 1988, Roulet 1990, Mausbach and Richardson 1994, Mitsch and Gosselink 2000, Rosenblatt et al. 2001, Tiner 2003, Zedler and Kercher 2005, Mitsch and Gosselink 2011, Kolka and Thompson 2012). In the United States slope wetlands are classified into two distinct forms; topographic slope wetlands and stratigraphic slope wetlands. Topographic slope wetlands are a result of concave landscapes that converge water, they often occur at the headwaters of streams and drainages. In the United States stratigraphic slope wetlands (hereafter SSWs) are a result of discharging ground water and can occur anywhere in dissected landscapes (Richardson and Brinson 2001). SSWs can be found at the base of slopes or further up the slope at a seepage face where groundwater discharges to the surface (Brinson 1993, 2009).

Although all wetlands may have a groundwater component, most (including topographic slope wetlands) have precipitation or surface water based hydrologic regimes
(Brinson 1993, Smith et al. 1995, Zedler and Kercher 2005). SSWs on the other hand have almost entirely groundwater dependent hydrologic regimes (Carter 1986, Winter 1988, Roulet 1990, Brinson 1993, Smith et al. 1995, Mitsch and Gosselink 2000, Richardson and Brinson 2001, Zedler and Kercher 2005, Mitsch and Gosselink 2011). This local groundwater discharge can supersede climatic conditions as the primary force behind wetland development (Semeniuk and Semeniuk 1995). SSWs are naturally isolated ecosystems (Amon et al. 2002, Bedford and Godwin 2003, Tiner 2003). This natural isolation can result in uniquely diverse plant communities (Weakley and Schafale 1994, Klijn and Witte 1999, Amon et al. 2002, Bedford and Godwin 2003, Leibowitz 2003, Diggelen et al. 2006) which can increase the beta diversity within a landscape (Brinson 1993, Weakley and Schafale 1994, Mitsch and Gosselink 2000), making SSWs important sites for local and even regional biodiversity (Leibowitz 2003, Tiner 2003).

In the Midwestern United States SSWs have been referred to by a multitude of terms (Table 1). The most commonly used term is "seep", however the term "fen" is also used frequently. Fens are often cited as an example of a slope wetland (Brinson 1993, Smith et al. 1995, Brinson 2009). Fens are typically defined as wetlands that are dominated by herbaceous forbs and non-emergent grasses and sedges, with a groundwater dependent hydrologic 
Table 1. Terminology used to describe stratigraphic slope wetlands in the Midwestern United States

\begin{tabular}{|c|c|c|}
\hline Term & Location (State) & References $^{\mathrm{a}}$ \\
\hline \multirow[t]{3}{*}{ bog } & Illinois & Gates (1912) \\
\hline & Indiana & Homoya (1984) \\
\hline & Iowa & Nekola and Lammers (1989) \\
\hline \multirow[t]{5}{*}{ fen } & Iowa & Thompson et al. (1992) \\
\hline & Kansas & Lauver et al. (1999) \\
\hline & Minnesota & Almendinger and Leete (1998) \\
\hline & Ohio & Andreas (1985) \\
\hline & Wisconsin & Curtis (1971) \\
\hline \multirow[t]{2}{*}{ hanging bog } & Iowa & Herzberg and Pearson (2001) \\
\hline & Wisconsin & Curtis (1971) \\
\hline hillside bog & Iowa & Nekola and Lammers (1989) \\
\hline hillside fen & Ohio & Bohrer et al. (2004) \\
\hline hillside marsh & Illinois & Henry et al. (1978) and previous authors \\
\hline \multirow[t]{3}{*}{ hillside seep } & Illinois & Ebinger (1978), Henry and Scott (1984) \\
\hline & Indiana & Ebinger and Bacone (1980) \\
\hline & Iowa & Herzberg and Pearson (2001) \\
\hline perched bog & Wisconsin & Curtis (1971) \\
\hline \multirow[t]{2}{*}{ prairie fen } & Illinois & Moran (1981) \\
\hline & Missouri & Orzell and Kurz (1986) \\
\hline \multirow[t]{5}{*}{ seep } & Illinois & McClain et al. (2008) and previous authors \\
\hline & Iowa & Nekola and Lammers (1989) \\
\hline & Kansas & Lauver et al. (1999) \\
\hline & Nebraska & Kaul et al. (1988) \\
\hline & Ohio & Mack (2009) \\
\hline seep fen & Missouri & Orzell and Kurz (1986) \\
\hline seep spring & Indiana & Homoya (1984) \\
\hline spring fen & Iowa & Nekola and Lammers (1989) \\
\hline
\end{tabular}

${ }^{\mathrm{a}}$ Selected references include only those that described at least some of the wetlands as being located on slopes or hillsides

regime and a carbon accumulating substrate such as peat or marl, and in a landscape position that rarely experiences inundation (Thompson et al. 1992, Amon et al. 2002, Bedford and Godwin 2003). In the state of Iowa the majority of fens are SSWs, being found along the sides of stream-valley slopes (Thompson et al. 1992, Thompson and Bettis 1994).

There is some ambiguity on the definition of a fen however (Bridgham et al. 1996, Bedford and Godwin 2003, Diggelen et al. 2006). Many definitions make reference to fens as peatland ecosystems (see Bridgham et al. 1996, Amon et al. 2002, Bedford and Godwin 2003, and Diggelen et al. 2006 for reviews). This concept is likely the result of a preponderance of literature on fens originating from northern areas where peat is a common feature of the landscape (Bedford and Godwin 2003). The classification of fens as peatland ecosystems may not be wholly applicable to Midwestern fens however. For example, both Midwestern fens and seeps can include an assortment of both organic and inorganic substrates (Phipps and Speer 1958, Ebinger and Bacone 1980, Homoya 1984, Amon et al. 2002). Fens have also been documented on mineral substrates in both North America and Europe (Nekola 1994, Halsey et al. 1998, Wheeler and Proctor 2000, Bedford and Godwin 2003, Diggelen et al. 2006). It has been suggested that the presence of peat should not be included in the definition of a fen (Nekola 1994, Wheeler and Proctor 2000, Bedford and Godwin 2003).
Fens have also been defined based on the presence of specific plant communities or indicator species (Bridgham et al. 1996, Amon et al. 2002, Bedford and Godwin 2003). However, this definition is also problematic. The uniqueness of Midwestern fens specifically has resulted in distinct plant assemblages (Pearson and Leoschke 1992, Amon et al. 2002, Bedford and Godwin 2003) that make it nearly impossible to classify any anticipated plant community or individual species as an indicator of a Midwestern fen ecosystem (Amon et al. 2002). Fens are dominated by sedges (Cyperaceae), grasses and herbaceous plants (Amon et al. 2002, Bedford and Godwin 2003). However, communities composed of these types of plants are not exclusive to fens; in other areas of the country they can dominate other groundwater wetlands as well (e.g. Goslee et al. 1997). In the Midwest the use of vegetation as a means of identifying fens is further complicated by the fact that fens and seeps have many of the same species in common (Eilers and Roosa 1994, Bowles et al. 2005).

Perhaps the only universally accepted factor in the definition of a fen is that their hydrology is groundwater based (Mausbach and Richardson 1994, Amon et al. 2002, Bedford and Godwin 2003, Diggelen et al. 2006). Groundwater based hydrology is not unique to fens however. Hydrology is the driving force behind wetland formation and maintaining the wetland environment (Carter 1986, Leibowitz 2003, Skaggs et al. 1994) and similar hydrologic environments can result in similar vegeta- 
tive communities across multiple landscape formations (Grootjans et al. 2006), potentially blurring the line between fens and seeps. All SSWs, regardless of their plant community and substrate, are ground water dependent ecosystems (Carter 1986, Winter 1988, Shaffer et al. 1999, Cole et al. 1997, Cole et al. 2002, Bedford and Godwin 2003), and with the exception of fens, they have rarely been studied (Roulet 1990, Whigham and Jordan 2003, Stein et al. 2004). In some areas of the glaciated Midwest SSWs often occur along similar topographic elevations, are similar in size, and tend to be dominated by the same plant species, regardless of whether they are considered fens or seeps (personal observation). The purpose of this study was to determine if there were any geomorphological differences that distinguish those SSWs recognized as fens from those that are considered seeps.

\section{Methods}

Thirty SSWs in Muscatine County, Iowa were selected for this study. The 30 sites were found by a combination of accidental discovery, conversations with landowners, and field verification of suspected sites that had been observed on aerial photographs. The first site was discovered in 2010 and the most recent in 2012. All 30 sites were privately owned. A review of relevant literature found that none of the 30 sites had been previously documented. All sites were located in a finger of the Southern Iowa Drift Plain landform region that occurs between the Iowa-Cedar Lowland and Mississippi River Alluvial Plain landform regions in southeastern Iowa (Prior 1991) (Fig. 1). The Southern Iowa Drift Plain is an old (500,000 yr. BP), dissected glacial landscape with a loess surface underlain by glacial till (Prior 1991).

All 30 SSWs were open (i.e., no woody vegetation or overstory canopy cover) and were the result of seepage faces situated at upper elevations on the slope. All sites met the vegetative and hydrologic requirements in most accepted definitions of a fen; i.e., dominated by non-emergent graminoids and forbs, possessing a groundwater based hydrology that maintained saturation in the root zone for most of the year, and located at a point on the landscape that did not experience inundation (Thompson et al. 1992, Amon et al. 2002, Bedford and Godwin 2003). Average annual precipitation for Muscatine County is $86.4 \mathrm{~cm}$ (Eilers and Roosa 1994). Plant species routinely observed on the majority of sites included Cardamine bulbosa (Schreb. ex Muhl.) Britton, Sterns \& Poggenb, Carex stricta Lam., Eupatorium maculatum L., Helianthus grosseserratus M. Martens, Typha latifolia L., and Saxifraga pensylvanica L. All of these species are commonly encountered in Midwestern fens (Pearson and Leoschke 1992, Amon et al. 2002) and are typically one or more of the dominant species in Iowa fens (Nekola 2004).

From August $26^{\text {th }}$ to August $30^{\text {th }}, 2013$ each SSW was visited and the perimeter was mapped with a differential global positioning system (DGPS) using ArcPad 8.0 SP4 field mapping software (ESRI, Redlands, California) on a Magellan MobileMapper 6 GPS unit (Thales Navigation, Santa Clara, California). In order to ensure the highest degree of accuracy, the Position Dilution of Precision (PDOP) was checked prior to mapping each SSW. The PDOP is a measure of the uncertainty in the horizontal and vertical data received by the GPS unit, the lower the PDOP value the greater the accuracy (Van Sickle 2001). PDOP values from 5 to 9 are generally accurate enough to be acceptable, PDOP values less than 4 are considered highly accurate (Farina 2006) and PDOP values of 2 or less are exceptional (Van Sickle 2001). The PDOP values before mapping each SSW ranged from 1.5 to 1.9 and averaged 1.7 (0.18 SD).

Each SSW exhibited surface soil saturation. The perimeter was defined as the point at which soil was no longer visibly saturated to the surface. Precipitation for the area 60 days prior had been below normal (Iowa State University 2013) and the area was considered abnormally dry for 21 days prior (Rippey 2013). Assessments of seepage areas during droughts allow for comparisons to be made based on groundwater discharge that has not been influenced by recent precipitation (Henry and Scott 1984, Nekola 2004). Therefore, due to the unusually dry conditions it was presumed that the saturation observed was the natural extent of the discharging groundwater. Soil saturation was observed to be most pronounced towards the center of each SSW. Consequently, soils in the center of each wetland were presumed to be the most influenced by the local hydrology and were considered representative of the conditions at each SSW. Soils were sampled in in the center of each SSW using a JMC Backsaver soil probe equipped with a $1.75 \mathrm{~cm}$ Wet Sample Tube (Clements Associates Inc., Newton, Iowa). Soils were described to a minimum depth of $40 \mathrm{~cm}$.

After collection in the field the data was uploaded to ArcMap 10.0 Geographic Information System (GIS) software (ESRI, Redlands, California). Four geomorphic characteristics were analyzed for each SSW; area in square meters $\left(\mathrm{m}^{2}\right)$, upslope elevation in meters above

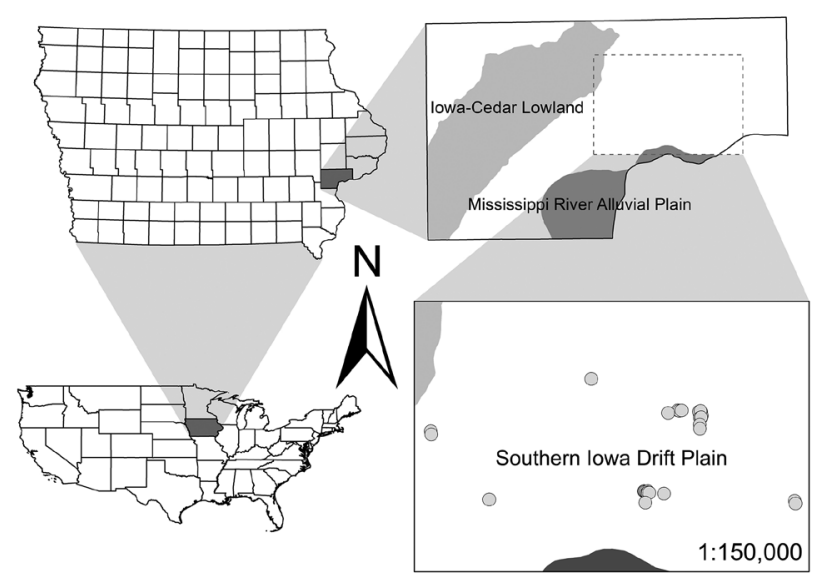

Fig. 1. Location of the study sites at national, state, county and local level

Circles represent the locations of SSWs examined during this study 
sea level ( $\mathrm{m}$ a.s.1.), slope in percent grade (\%), and soil parent material. Area was measured in meters to the nearest hundredth using the GPS data collected in the field. The upslope elevation was determined by using the Create Contours function in the 3D Analyst toolbar in ArcMap at the furthest upslope GPS data point for each SSW. Upslope elevation was measured to the nearest hundredth in $\mathrm{m}$ a.s.l. Slope was defined as the percent grade along the widest section of the seepage face of each SSW. Slope was determined using the Interpolate Line and Profile Graph functions in the 3D Analyst Toolbar and was measured to the nearest tenth of a percent. The input raster for both was a LiDAR Digital Elevation Model with $1 \mathrm{~m}$ elevation resolution (Iowa Department of Natural Resources 2010).

Using the soil profile descriptions each SSW was then categorized into one of two groups based on the level of development of a carbon accumulating substrate. The formation of carbon accumulating substrates, including histic deposits, has been suggested as a required criterion in the definition of Midwestern fens (Amon et al. 2002). Therefore, SSWs with histic epipedons extending for 20 $\mathrm{cm}$ or more in depth were considered to have a well-developed carbon accumulating substrate and were categorized as "Fens". SSWs with histic epipedons extending for less than $20 \mathrm{~cm}$ in depth, or those without a histic epipedon, were considered to have little or no carbon accumulation and were categorized as "Seeps". The minimum depths used to categorize each site were based on the accepted criteria for a histic epipedon (Soil Survey Staff 2010).

Parent material was determined for each Fen and Seep by identifying the mapped soil unit from the Muscatine County USDA-NRCS Soil Survey Geographic Database (SSURGO) (Soil Survey Staff 2003) and then obtaining the parent material from the Official Soils Series Description database (Soil Survey Staff 2013). In Iowa, the majority of fens occur on slopes underlain by glacial till (Thompson et al. 1992). Therefore, Fens and Seeps were divided into one of two categories, those with glacial till parent material (Till) and those with other parent materials (e.g. loess, alluvium) (Non-Till). This resulted in a total of four groupings; Fens on Till, Fens on Non-Till, Seeps on Till, and Seeps on Non-Till. One-way ANOVA was utilized to test the hypotheses that the area $\left(\mathrm{H}_{1}\right)$, upslope elevation $\left(\mathrm{H}_{2}\right)$, and/or slope $\left(\mathrm{H}_{3}\right)$ would be significantly different between Seeps and Fens of differing parent material $\left(\mathrm{H}_{0}=\right.$ No difference $)$. A Chi-Square test was also utilized to test the hypothesis that the number of Fens or Seeps would be dependent on the underlying parent material $\left(\mathrm{H}_{0}=\right.$ No difference $)$. All statistical analysis was completed at $95 \%$ significance $(\alpha-0.05)$.

\section{Results}

Only 28 of the initial 30 sites selected for this study were utilized in the final analysis. Two of the sites (21 and 24) were excluded from the final analysis because of condi- tions observed in the field. Site 21 showed evidence of past hydrologic manipulation; specifically, the presence of a berm constructed along the length of the SSW below the seepage face. The berm appeared to have been constructed to divert overland flow exiting from the seepage face so the area downslope would not become saturated. This structure also impounded some water behind it which effectively altered the hydrology (making the site wetter than it would be naturally). Site 24 had a plant community composed entirely of exotic and annual species, while all other sites were dominated by native perennials. Unlike the remaining sites, which were surrounded by a matrix of cool season grass pasture, site 24 was within a few meters of an annually-tilled crop field. Soil sampling suggested that this site had also been subject to repeated siltation by erosion from the nearby upslope field. Based on these conditions, both of these sites were discarded from the final analysis due to the presence of anthropogenic alteration.

Of the remaining 28 sites, 17 were classified as Seeps and 11 as Fens based on the characteristics of the soil profiles (Fig. 2). In each of the Seep sites a depleted or gleyed matrix was observed starting within $25 \mathrm{~cm}$ or less of the surface. On 7 of the Fen sites histic epipedons extended for more than $40 \mathrm{~cm}$ in depth, while on the remaining 4 sites they were greater than 20 but less than $40 \mathrm{~cm}$. With the exception of one of the discarded sites (Site 24), no sites exhibited any form of intermediate or transitional organic soil development (i.e., histic epipedons less than $20 \mathrm{~cm}$ in depth). The data are summarized in Table 2. Table 2 also includes the Hydric Soil Indicator observed at each site. The Hydric Soil Indicators are regionally specific features observed in the soil profile that identify soils as wetland soils (USDA-NRCS 2010). Among the 11 Fen sites, 6 occurred on Till parent materials and 5 were found on NonTill. While 12 of the Seeps were found on Till and the remaining 5 were underlain by Non-Till parent materials. The Chi-Square test indicated that there was not a significant difference between the number of Fens or Seeps on Till and Non-Till parent materials; $\chi^{2}=0.7487, \mathrm{~N}=28, p=0.39$.

All SSWs combined ranged in area from 97.61 to $3391.25 \mathrm{~m}^{2}$ and averaged $1107.72(\mathrm{SD}=818.34) \mathrm{m}^{2}$. Fens ranged in size from 97.61 to $2786.11 \mathrm{~m}^{2}\left(\bar{x}=1285.77 \mathrm{~m}^{2}\right.$, $\mathrm{SD}=876.64$ ) and Seeps ranged in area from 241.14 to

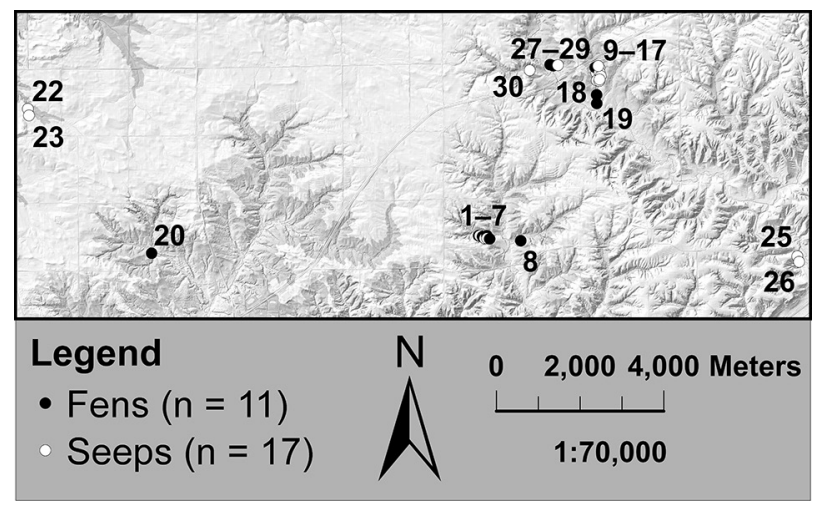

Fig. 2. Relief map with locations of Fens and Seeps in Muscatine County, Iowa examined in this study 
Table 2. Geomorphic measurements and classifications of stratigraphic slope wetlands examined in Muscatine County, Iowa

\begin{tabular}{|c|c|c|c|c|c|c|c|}
\hline \multirow{2}{*}{$\begin{array}{c}\text { Site } \\
\text { Number }\end{array}$} & $\begin{array}{c}\text { Upslope } \\
\text { Elevation }\end{array}$ & Area & Slope & Perimeter & \multirow{2}{*}{$\begin{array}{l}\text { Hydric Soil } \\
\text { Indicator }^{\mathrm{a}}\end{array}$} & \multirow[t]{2}{*}{ Category } & \multirow[t]{2}{*}{ Parent Materia } \\
\hline & [m a.s.1.] & {$\left[\mathrm{m}^{2}\right]$} & {$[\%]$} & {$[\mathrm{m}]$} & & & \\
\hline 1 & 202.39 & 134.41 & 11.1 & 51.57 & A1 & Fen & Till \\
\hline 2 & 203.00 & 930.78 & 5.9 & 138.78 & A11 & Seep & Till \\
\hline 3 & 202.39 & 813.01 & 5.5 & 156.33 & $\mathrm{~A} 2$ & Fen & Till \\
\hline 4 & 201.78 & 1208.09 & 8.1 & 147.71 & F3 & Seep & Till \\
\hline 5 & 197.51 & 97.61 & 29.8 & 38.34 & $\mathrm{~A} 2$ & Fen & Till \\
\hline 6 & 201.17 & 1006.11 & 13.2 & 127.80 & F3 & Seep & Till \\
\hline 7 & 199.95 & 1058.68 & 5.2 & 150.54 & A2 & Fen & Non-Till \\
\hline 8 & 195.07 & 646.82 & 11.2 & 149.90 & A1 & Fen & Till \\
\hline 9 & 199.34 & 1274.42 & 6.3 & 204.06 & A11 & Seep & Till \\
\hline 10 & 201.78 & 2786.11 & 8.1 & 419.40 & A1 & Fen & Till \\
\hline 11 & 198.73 & 1635.4 & 4.7 & 161.09 & A11 & Seep & Till \\
\hline 12 & 198.12 & 760.84 & 16.4 & 208.15 & A11 & Seep & Till \\
\hline 13 & 198.12 & 324.99 & 13.0 & 134.26 & A11 & Seep & Till \\
\hline 14 & 198.73 & 251.04 & 14.5 & 110.25 & A11 & Seep & Till \\
\hline 15 & 195.68 & 656.56 & 8.4 & 170.14 & A11 & Seep & Till \\
\hline 16 & 195.68 & 638.42 & 13.7 & 98.21 & A11 & Seep & Till \\
\hline 17 & 198.12 & 241.14 & 7.9 & 98.18 & A11 & Seep & Till \\
\hline 18 & 194.46 & 1416.42 & 6.0 & 176.78 & $\mathrm{~A} 2$ & Fen & Till \\
\hline 19 & 192.64 & 984.96 & 8.6 & 154.47 & A1 & Fen & Non-Till \\
\hline 20 & 201.17 & 2192.87 & 5.8 & 231.10 & A1 & Fen & Non-Till \\
\hline 22 & 210.92 & 1791.13 & 14.8 & 204.43 & F3 & Seep & Non-Till \\
\hline 23 & 212.75 & 3391.25 & 4.4 & 356.01 & F3 & Seep & Non-Till \\
\hline 25 & 180.44 & 1005.53 & 10.3 & 272.16 & $\mathrm{~F} 2$ & Seep & Non-Till \\
\hline 26 & 181.66 & 1184.73 & 8.3 & 286.94 & $\mathrm{~F} 2$ & Seep & Non-Till \\
\hline 27 & 196.90 & 1856.79 & 6.1 & 183.31 & A1 & Fen & Non-Till \\
\hline 28 & 196.90 & 2155.73 & 2.2 & 234.85 & A1 & Fen & Non-Till \\
\hline 29 & 197.51 & 277.41 & 13.3 & 72.91 & F2 & Seep & Non-Till \\
\hline 30 & 201.02 & 294.91 & 20.6 & 75.90 & F3 & Seep & Till \\
\hline
\end{tabular}

${ }^{a}$ The dominant indicator from the Field Indicators of Hydric Soils, Ver. 7 (USDA-NRCS 2010)

Table 3. Sizes of Fens and Seeps on Till and Non-Till parents materials in Muscatine County, Iowa

\begin{tabular}{ccc}
\hline & Fen $\left(\mathrm{m}^{2}\right)$ & Seep $\left(\mathrm{m}^{2}\right)$ \\
\cline { 2 - 3 } & 97.61 & 241.14 \\
& 134.41 & 251.04 \\
& 646.82 & 294.91 \\
& 813.01 & 324.99 \\
$\bar{x}=839.84 \mathrm{~m}^{2}$ & 1416.42 & 638.42 \\
$(\mathrm{SD}=666.32)$ & 2786.11 & 656.56 \\
& & 760.84 \\
& & 930.78 \\
& & 1006.11 \\
& & 1208.09 \\
& & 1274.42 \\
& & 1635.40 \\
& & $\bar{x}=768.56$ \\
& & $(\mathrm{SD}=455.26)$ \\
\hline Non-Till & 984.40 & 277.41 \\
$(\mathrm{SD}=876.66)$ & 1058.68 & 1005.53 \\
& 1856.79 & 1184.73 \\
& 2155.73 & 1791.13 \\
& 2192.87 & 3391.25 \\
& $\bar{x}=1649.81$ & $\bar{x}=1530.01$ \\
& $(\mathrm{SD}=588.47)$ & $(\mathrm{SD}=1172.15)$ \\
\hline
\end{tabular}

Table 4. Elevations of Fens and Seeps on Till and Non-Till parents materials in Muscatine County, Iowa

\begin{tabular}{|c|c|c|}
\hline \multirow{15}{*}{$\begin{array}{c}\text { Till } \\
\bar{x}=199.06 \mathrm{~m} \text { a.s.1. } \\
(\mathrm{SD}=2.73)\end{array}$} & Fen (m a.s.1.) & Seep (m a.s.l.) \\
\hline & 194.46 & 195.68 \\
\hline & 195.07 & 195.68 \\
\hline & 197.51 & 198.12 \\
\hline & 201.78 & 198.12 \\
\hline & 202.39 & 198.12 \\
\hline & 202.39 & 198.73 \\
\hline & & 198.73 \\
\hline & & 199.34 \\
\hline & & 201.02 \\
\hline & & 201.17 \\
\hline & & 201.78 \\
\hline & & 203.00 \\
\hline & $\bar{x}=198.93$ & $\bar{x}=199.12$ \\
\hline & $(\mathrm{SD}=3.71)$ & $(\mathrm{SD}=2.28)$ \\
\hline \multirow{7}{*}{$\begin{array}{c}\text { Non-Till } \\
\bar{x}=197.08 \mathrm{~m} \text { a.s.1. } \\
(\mathrm{SD}=10.52)\end{array}$} & 192.64 & 180.44 \\
\hline & 196.90 & 181.66 \\
\hline & 196.90 & 197.51 \\
\hline & 199.95 & 210.92 \\
\hline & 201.17 & 212.75 \\
\hline & $\bar{x}=197.51$ & $\bar{x}=196.66$ \\
\hline & $(\mathrm{SD}=3.31)$ & $(\mathrm{SD}=15.42)$ \\
\hline
\end{tabular}


Table 5. Slopes of Fens and Seeps on Till and Non-Till parents materials in Muscatine County, Iowa

\begin{tabular}{|c|c|c|}
\hline \multirow{15}{*}{$\begin{array}{c}\text { Till } \\
\bar{x}=11.4 \% \\
(\mathrm{SD}=6.3)\end{array}$} & Fen $(\%)$ & Seep (\%) \\
\hline & 5.5 & 4.7 \\
\hline & 6.0 & 5.9 \\
\hline & 8.1 & 6.3 \\
\hline & 11.1 & 7.9 \\
\hline & 11.2 & 8.1 \\
\hline & 29.8 & 8.4 \\
\hline & & 13.0 \\
\hline & & 13.2 \\
\hline & & 13.7 \\
\hline & & 14.5 \\
\hline & & 16.4 \\
\hline & & 20.6 \\
\hline & $\bar{x}=12.0$ & $\bar{x}=11.1$ \\
\hline & $(\mathrm{SD}=9.1$ & $(\mathrm{SD}=4.9$ \\
\hline \multirow{7}{*}{$\begin{array}{c}\text { Non-Till } \\
\bar{x}=7.9 \% \\
(\mathrm{SD}=4.0)\end{array}$} & 2.2 & 4.4 \\
\hline & 5.2 & 8.3 \\
\hline & 5.8 & 10.3 \\
\hline & 6.1 & 13.3 \\
\hline & 8.6 & 14.8 \\
\hline & $\bar{x}=5.6$ & $\bar{x}=10.2$ \\
\hline & $(\mathrm{SD}=2.3)$ & $(\mathrm{SD}=4.1)$ \\
\hline
\end{tabular}

$3391.25 \mathrm{~m}^{2}\left(\bar{x}=992.52 \mathrm{~m}^{2}, \mathrm{SD}=783.50\right)$. Differences in size between Till and Non-Till sites are summarized in Table 3. There was no significant difference between the size of Seeps and Fens among the different parent materials; $\mathrm{F}(3,24)=2.154, p=0.12$.

The upslope elevation for all SSWs ranged from 180.44 to $212.75 \mathrm{~m}$ a.s.1. and averaged $198.36 \mathrm{~m}$ a.s.l. $(\mathrm{SD}=6.52)$. Fens ranged from 192.64 to $202.39 \mathrm{~m}$ a.s.l. and averaged 198.29 m a.s.l. $(\mathrm{SD}=3.44)$. Seeps ranged from 180.44 to $212.75 \mathrm{~m}$ a.s.l. and averaged $198.40 \mathrm{~m}$ a.s.l. $(\mathrm{SD}=8.02)$. Differences in elevation between Till and Non-Till sites are summarized in Table 4. Fens on Till, Fens on NonTill, and Seeps on Till all had a much narrower range of upslope elevations than Seeps underlain by Non-Till. However, this difference was not statistically significant; $\mathrm{F}(3,24)=0.193, p=0.90$.

Slopes for all SSWs combined ranged from 2.2 to $29.8 \%$ and averaged $10.1 \%(\mathrm{SD}=5.8)$. Fen slopes ranged from 2.2 to $29.8 \%(\bar{x}=9.1 \%, \mathrm{SD}=7.4)$ and Seep slopes ranged from 4.4 to $20.6 \%(\bar{x}=10.8 \%, \mathrm{SD}=4.6)$. Differences in slope between Till and Non-Till sites are summarized in Table 5. There was no significant difference between the slopes of Fens and Seeps underlain by Till and Non-Till parent materials; $\mathrm{F}(3,24)=1.403, p=0.27$.

\section{Discussion}

Hydric soil morphology was relatively consistent for Seeps and Fens. The presence of a depleted or gleyed matrix, which are characterized by low-chroma colors, correlate with the depth of the water table (Zobeck and Ritchie 1984, Guertal and Hall 1990, James and Fenton 1993, Kolka and Thompson 2012), suggesting that each of the Seep sites experiences long-term high water tables (within $25 \mathrm{~cm}$ or less of the surface). Thompson et al. (2007) observed this same pattern in SSWs lacking histic deposits in Kentucky where depleted matrices were also present within $25 \mathrm{~cm}$ or less of the soil surface.

The soil profiles in most of the Fens $(64 \%)$ met the conditions of a Histosol (a layer of sapric material $40 \mathrm{~cm}$ or more in depth) (Soil Survey Staff 2010) and would most certainly meet the requirements of a well-developed, carbon accumulating substrate as defined by Amon et al. (2002). Although the remaining four Fens had histic epipedons (sapric soil material less than $40 \mathrm{~cm}$ in depth), they were not deep enough to be classified as Histosols (Soil Survey Staff 2010). In the Midwest, sites such as these are usually considered sedge meadows instead of fens (Amon et al. 2002). However, there is no minimum required depth of histic material in any published definition of a fen for the United States. Also, the term sedge meadow has been used interchangeably with both fen (Mausbach and Richardson 1994, Middleton et al. 2006) and seep (Henry and Scott 1984). And there is no consensus among fen researchers as to whether or not fen and sedge meadow ecosystems are separate and distinct from one another (Middleton et al. 2006). For the purposes of this study, differentiating between Fens with Histosols and those with histic epipedons would have been arbitrary due to the vagueness in the definition of a fen.

In general, SSWs are relatively small (Roulet 1990, Mausbach and Richardson 1994) and most fens in the United States are considered small (Bedford and Godwin 2003). However, small is a relative term. Bedford and Godwin (2003) described fens in the United States as ranging from a few to several ha and in southern Missouri the sloped fens that Orzell and Kurz (1986) studied ranged from $6,000 \mathrm{~m}^{2}$ to $68,000 \mathrm{~m}^{2}$ ( $6.8 \mathrm{ha}$ ). Thompson and Bettis (1994) listed the range of sizes for Iowa fens from $4,000 \mathrm{~m}^{2}$ to $100,000 \mathrm{~m}^{2}$ (10 ha). All of the sites examined in this study fell below the $4,000 \mathrm{~m}^{2}$ lower value observed by Thompons and Bettis (1994). And those sites categorized as Fens were even smaller, with the largest Fen less than $3,000 \mathrm{~m}^{2}$ in area. SSWs of this size occur throughout eastern Iowa (personal observation). Therefore, the larger sizes described by other researchers for small fens is most likely due to a lack of research on SSWs that has resulted in very small fens being overlooked.

Substantial variation can exist between the sizes of slope wetlands due to the variation in local geologic and groundwater features (Winter 1988, Brinson 1993). This variation may be less pronounced in areas with similar geology and topography however, as indicated by the lack of significant differences between Fens and Seeps observed in this study. For SSWs this lack of variation may exist on a regional scale as there appears to be relative consistency in the size of Midwestern SSWs. For example, in Parke County, Indiana two SSWs studied by Ebinger and Bacone (1980) measured 1,480 $\mathrm{m}^{2}$ and 2,132 $\mathrm{m}^{2}$ in area, in Cole County, Illinois SSWs ranged in size from $18.6 \mathrm{~m}^{2}$ to $371.6 \mathrm{~m}^{2}$ (Parker et al. 1970, Parker and 
Ebinger 1971), and in McDonough County, Illinois SSWs were 91.6 to $689.8 \mathrm{~m}^{2}$ in size (Henry and Scott 1984). A group of 7 SSWs across a four-county area in east-central Illinois ranged from 185.8 to $3372.4 \mathrm{~m}^{2}$ and averaged $956.9 \mathrm{~m}^{2}(\mathrm{SD}=1155.3)$ (Ebinger 1978). McClain et al. (2008) observed that Illinois SSWs were rarely larger than $5,000 \mathrm{~m}^{2}$. The results of this study and the previously cited examples suggest that this limit may be consistent across the Midwestern United States.

Due to their small size wetlands located in upland areas typically go unnoticed (Weakley and Schafale 1994). Most fens are not of sufficient size to be delineated on topographic maps (Andreas 1985, Bedford and Godwin 2003) and slope wetlands in general are rarely indicated on U.S. Department of Agriculture soil survey maps (Weakley and Schafale 1994). None of the SSWs examined in this study were designated on topographic or soil maps. The small sizes of Midwestern SSWs prevent them from being included on soil survey maps because soil inclusions less than $10,000 \mathrm{~m}^{2}$ are typically below the minimum delineation size (Soil Survey Division Staff 1993). This pattern has been historically present in Iowa. For example, Bishop's (1981) paper on wetland loss in Iowa did not include the loss of fens or sedge meadows in the state (Eilers and Roosa 1994). Regardless of whether they are Seeps or Fens, SSWs are so small in size that they are often disregarded during natural feature inventories.

Very little published data exists on the elevations of SSWs; however some research has found Midwest SSWs with similar elevations to those observed in this study. For example, Parker et al. (1970) and Parker and Ebinger (1971) studied a series of seeps in Cole County, Illinois, which they reported to be at elevations of approximately $180 \mathrm{~m}$ a.s.l. and Andreas (1985) described peatlands in Ohio (including fens located on glacial moraines) with elevations ranging from 110 to $218 \mathrm{~m}$ a.s.l. Fens in this study were confined to a much narrower band of upslope elevations than some Seeps. However, the lack of a statistically significant difference between the elevations of Seeps and Fens supports the conclusion that Seeps and Fens in the study area do not occur at different elevations. Similar results were observed in Ohio, where no characteristic topographic relationships were detected among fens (Andreas 1985) and in Indiana, where seeps and fens occurred at analogous positions on the landscape (Hicks 2012).

Fens on hillsides will exhibit a sharp border along the upslope boundary between the mineral soil of the neighboring upland and the organic soil of the fen (Amon et al. 2002). This boundary was present on all of the sites classified as Fens during this study and was also observed on each of the Seep sites as well. This suggests that this edge feature is not exclusive to fens and may be a result of processes other than organic soil formation. Groundwater discharging from a slope will result in slope failure until the hydraulic gradient is parallel to the slope, at which point the slope becomes stable (Budhu and Gobin 1996). SSWs with similar hydrologic regimes should therefore exhibit this same upland border phenomenon regardless of whether or not they are accumulating histic deposits, as was observed in this study.

Fens occur across a wide range of slopes (Thompson et al. 1992, Amon et al. 2002). In southern Missouri hillslope fens occur on slopes between 5 and 45\% (Orzell and Kurz 1986). Thompson and Bettis (1994) observed that slopes in Iowa fens typically range from 0.4 to $24.3 \%$ with the majority $(90 \%)$ occurring on slopes less than $10 \%$. Similar ranges for slopes were observed for Fens during this study. Of the 11 Fens, 7 (73\%) had slopes less than $10 \%, 2(18 \%)$ had slopes greater than $10 \%$ but less than $24.3 \%$, and only $1(9 \%)$ had a slope outside the range cited by Thompson and Bettis (1994) (29.8\%). This outlier also did not have histic deposits greater than $40 \mathrm{~cm}$ in depth which, under some definitions (i.e., Amon et al. 2002), would mean the site was a sedge meadow and not a fen. A gentler slope would slow runoff thereby keeping the soil saturated longer and promote the development of organic soil on those sites as opposed to those with steeper slopes (Amon et al. 2002).

All of the Seeps examined in this study also fell within Thompson and Bettis (1994) range and nearly half of these sites ( 8 out of 17 ) had slopes less than $10 \%$. Since all of the sites were saturated at the surface during abnormally dry conditions it was assumed that the groundwater discharge was relatively consistent between all sites, yet histic deposits have so far failed to develop on any of the Seeps. Clearly a shallower slope in and of itself is not enough to facilitate development of histic deposits. There is no published data on the slopes of seeps in Iowa; however in Rhode Island Rosenblatt et al. (2001) did not find any relationship between slope and the presence or absence of a seep. Based on the results of this study, it would appear that slope is not a significant geomorphic factor in differentiating between Seeps and Fens. However, under certain conditions a shallower slope may expedite the development and accumulation of histic deposits.

Local geologic conditions, such as bedrock and glacial deposits, exert substantial influence on the development and distribution of SSWs (Thompson and Bettis 1994, Bedford and Godwin 2003, Stein et al. 2004). Fens in Iowa have formed over a variety of parent materials; however most have developed over glacial till (Thompson et al. 1992, Nekola 1994). Data on the parent material of other Midwestern SSWs is lacking but results from other areas of the country suggest a similar relationship to that observed for Iowa fens. For example, Thompson et al. (2007) found that SSWs in southeastern Kentucky were all underlain by the same bedrock material and in southern Rhode Island seeps were found more frequently on sites underlain by glacial till (Rosenblatt et al. 2001).

Many SSWs, regardless of whether they are fens or seeps, occur in series across valley slopes and may be grouped within a small area (Parker et al. 1970, Parker and Ebinger 1971, Thompson and Bettis 1994). This pattern was observed several times during this study on sites 1 through 7, 9 through 17, and sites 27 through 29 . Fens and Seeps were clustered within very close prox- 
imity to one another in the same valley. For example, on sites 1 through 7 a group of 3 Fens and 4 Seeps occurred together, on average, within $35 \mathrm{~m}$ of each other (Fig. 3). These sites also displayed varying degrees of histic development. Site \#1 possessed a histic epipedon greater than $40 \mathrm{~cm}$ in depth (Histosol). Site \#2, which was only $5 \mathrm{~m}$ away from Site \#1, lacked any histic development and had a depleted matrix. And Site \#3, which was $25 \mathrm{~m}$ away from Site \#2, had a histic epipedon greater than 20, but less than $40 \mathrm{~cm}$ in depth. Thus, a "fen", a "seep" and a "sedge meadow" (using carbon-accumulation as a defining characteristic) appear to have developed as separate and distinct communities, with similar geomorphological features, in extremely close vicinity to one another.

The lack of significant differences between Fens and Seeps of different parent materials, and the tendency for both types of SSWs to occur in such close proximity to one another, suggests that subtle differences in hydrology and/or vegetation may have a greater influence on the development of a fen than geomorphic characteristics. Slight variations in the subsurface soil and geology may play an important in role in these differences. For example, Miner and Ketterling (2003) found that the irregular gravel subsurface of a northeastern Illinois fen influenced the hydrology of the site and the corresponding development of histic surface material. Glacial landscapes are some of the most hydrological complex environments (Winter 2001) and groundwater discharge is not equally distributed across slopes (Winter 1999). The closeness of Seeps and Fens in this study suggests that the effect of localized subsurface features on groundwater discharge may be specific down to scales as small as a few meters.

Although 4 of the 11 Fens in this study would be considered sedge meadows by some authorities due to the histic material being less than $40 \mathrm{~cm}$ in depth, the lack of any intermediary histic development (i.e., between 1 and $20 \mathrm{~cm}$ in depth) on any of the 28 sites is puzzling. This may be an artifact of local conditions in the small geographic range of the sample. In other Midwestern states many SSWs denoted as seeps in the literature have been

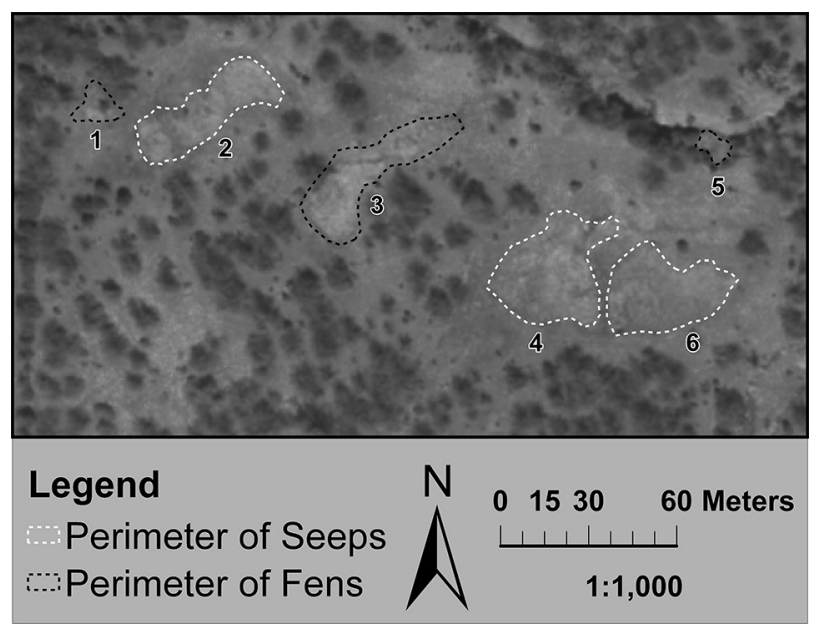

Fig. 3. 2013 Aerial photograph of Fens and Seeps in a series along a stream valley in Muscatine County, Iowa described as having histic deposits (Phipps and Speer 1958, Parker and Ebinger 1971, O'Flaherty et al. 1975, Ebinger and Bacone 1980, Homoya 1984, McClain et al. 2008, Hicks 2012). However, few of these studies have provided detailed descriptions of the depth of the histic material, instead using indefinite terms such as "deep" and "shallow". Even fens have been described this way. For example, in Missouri, Orzell and Kurz (1986) described fens on slopes (which they termed "prairie fens") as having "shallow histic epipedons". The absence of any intermediate histic accumulation that divided Fens and Seeps may in fact be a distinguishing characteristic; however more research is needed to confirm this division.

The formation of histic deposits is closely associated with hydrology, especially under conditions of soil saturation (Moore 1989), and wetlands with groundwater based hydrology often have greater consistency with their hydrologic regimes than those that are precipitation or surface based (Kolka and Thompson 2012). However, subtle differences in hydrology may prevent organic soil from developing (Bowles et al. 2005, Skalbeck et al. 2009). Eastern Iowa fens tend to experience greater variability in their hydrology than fens in the western half of the state (Thompson et al. 1992). This variability can impact their rate of decomposition and peat accumulation (Thompson and Bettis 1994). Fens are also extremely susceptible to changes in their hydrologic regime (Zimmerman 1976, Moran 1981, Almendinger and Leete 1998, Diggelen et al. 2006). Grootjans et al. (2006) noted that this vulnerability extended to all "small groundwater-fed systems". Wetlands with similar geomorphic features are usually impacted by the same forms of disturbance (Brinson and Malvárez 2002). Due to the similar hydrologic and geomorphic conditions required for their formation it stands to reason that all SSWs are particularly vulnerable to changes in their hydrology.

Plant communities in the adjacent landscape can influence local water tables (Zhang and Schilling 2006). In the Midwest, much of the wetland loss is a result of converting the landscape to agricultural production (Brinson and Malvárez 2002). The conversion of the surrounding landscape has undoubtedly impacted all of these sites. The removal of deep-rooted native perennials in exchange for shallow-rooted annual crops can reduce evapotranspiration and increase groundwater discharge (Saunders et al. 1991). Thus, groundwater outflow may have increased in some sites and accelerated the accumulation of histic deposits. Large-scale artificial drainage networks have also been installed throughout the Midwest to facilitate agriculture (Blann et al. 2009). These networks can lower both local and regional water tables (Winter1988, Blann et al. 2009, Diggelen et al. 2006). This can result in fens that still display the characteristic groundwater discharge, but at a reduced rate, which can lead to an increased rate of soil mineralization (Grootjans et al. 2006, Diggelen et al. 2006). Conversely, it is possible that all of the Seeps in this study, and in other areas impacted by artificial drainage, are in fact hydrologically degraded fens. 


\section{Summary}

This study documented 7 previously unknown sites that met accepted criteria for a fen (e.g. Thompson et al. 1992, Amon et al. 2002, Bedford and Godwin 2003). In Iowa fens are typically regarded as features of the northern portion of the state (Pearson and Leoschke 1992). And in the Southern Iowa Drift Plan landform region, where this study took place, few fens have been documented and their absence from this landform region is perplexing (Thompson et al. 1992). Fens on slopes have been documented from more southerly latitudes, such as southern Missouri (Orzell and Kurz 1986). And small SSWs, including some that meet Amon et al. (2002) criteria for a Midwestern fen, are also known to occur in other counties in the Southern Iowa Drift Plain (personal observation). Since fen research has traditionally focused on northern locations (Bedford and Godwin 2003) the absence of reported fens from this landform region is most likely the result of a lack of research and/or interest in SSWs in this landscape, rather than a difference in distribution.

Fens on Midwestern slopes exhibit substantial variation in their surface characteristics (Amon et al. 2002). In east-central Iowa Seeps also display substantial variation in surface characteristics; however this variation is not significant enough to distinguish Fens and Seeps as separate geomorphic features in the landscape. Given the lack of geomorphological differences between Seeps and Fens and the close proximity that some Seeps and Fens occur with one another, it would suggest that rather than being distinct features, Seeps and Fens represent a continuum across a hydrogeomorphic gradient in this area. Similar gradients have been observed among plant communities of fens, seeps, and sedge meadows in the Midwest (Pearson and Leoschke 1992, Amon et al. 2002, Bowles at al. 2005).

The interrelationship between vegetation, soil development, and hydrology in groundwater discharge areas is complex (Carter 1986, Klijn and Witte 1999). Since the presence of an organic soil may not be a necessary requirement for the formation of a fen (Nekola 1994, Wheeler and Proctor 2000, Bedford and Godwin 2003, Amon et al. 2005) any SSW with the appropriate hydrology may be capable of supporting fen, or fen-like, plant communities (Goslee et al. 1997, Morley and Calhoun 2009). Although divisions have been documented between local seep and fen plant communities (Hicks 2012), these differences may be a condition of local circumstances rather than a community characteristic since regionally Midwestern fens are too diverse and unique to categorize based on plant communities (Amon et al. 2002).

The use of ambiguous terminology such as "deep" and "shallow" to describe the depth of histic deposits, the lack of any suggested depth of histic development that distinguishes a fen, and the interchangeable use of the terms seep, fen, and even sedge meadow further complicate any attempt at meaningful classification. If a geomorphic distinction between seeps and fens does exist it may be due to subtle, local variations in subsurface characteris- tics that are individual to each site, which in turn, may result in equally individual hydrologic regimes and plant communities. Additional botanical, hydrological and soils research are necessary to clarify the distinction between the two. Clearly, there is still much to debate on what qualifies as a fen.

\section{Acknowledgements}

I would like to thank Dan Tufford for his advice on the statistical analysis as well his suggestions after reviewing an earlier version of this manuscript. I also thank an anonymous reviewers for their comments and suggestions which greatly improved this manuscript.

\section{References}

Almendinger J.E., Leete J.H., 1998. Peat characteristics and groundwater geochemistry of calcareous fens in the Minnesota River Basin, U.S.A. Biogeochemistry 43: 17-41. DOI: 10.1023/A:1005905431071.

Amon J.P., Thompson C.A., Carpenter Q.J., Miner J., 2002. Temperate zone fens of the glaciated Midwestern USA. Wetlands 22: 301-317. DOI: 10.1672/0277-5212(2002)022[0301:TZFOTG]2.0.CO;2.

Amon J.P., Jacobson C.S., Shelley M.L., 2005. Construction of fens with and without hydric soils. Ecological Engineering 24: 341-357. DOI: 10.1016/j.ecoleng.2004.11.011.

Andreas B.K., 1985. The relationship between Ohio peatland distribution and buried river valleys. Ohio Journal of Science 85: 116-125.

Bedford B.L., Godwin K.S., 2003. Fens of the United States: distribution, characteristics, and scientific connection versus legal isolation. Wetlands 23: 608-629. DOI: 10.1672/0277-5212(2003)023[0608:FOTUSD]2.0.CO;2.

Bishop R.A., 1981. Iowa's wetlands. Proceedings of the Iowa Academy of Science 88: 11-16.

Blann K.L., Anderson J.L., Sands G.R., Vondracek B., 2009. Effects of agricultural drainage on aquatic ecosystems: A review. Critical Reviews in Environmental Science and Technology 39: 909-1001. DOI: 10.1080/10643380801977966.

Bohrer K.E., Friese C.F., Amon J.P., 2004. Seasonal dynamics of arbuscular mycorrhizal fungi in differing wetland habitats. Mycorrhiza 14: 329-337. DOI: 10.1007/s00572-004-0292-7.

Bowles M.L., Kelsey P.D., McBride J.L., 2005. Relationships among environmental factors, vegetation zones, and species richness in a North American calcareous fen. Wetlands 25: 685-696. DOI: 10.1672/0277-5212(2005)025[0685:RAEFVZ]2.0.CO;2.

Bridgham S.D., Pastor J., Janssens J.A., Chapin C., Malterer T.J., 1996. Multiple limiting gradients in peatlands: A call for a new paradigm. Wetlands 16: 45-65. DOI: 10.1007/BF03160645.

Brinson M.M., 1993. A hydrogeomorphic classification for wetlands. U. S. Army Corps of Engineers Waterways Experiment Station, Vicksburg.

Brinson M.M., 2009. The United States HGM (hydrogeomorphic) approach. In: E. Maltby, T. Barker (eds), The wetlands handbook. Wiley-Blackwell Publishers, Hoboken: 486-512.

Brinson M.M., Malvárez A.I., 2002. Temperate freshwater wetlands: types, status, and threats. Environmental Conservation 29: 115-133. DOI: 10.1017/S0376892902000085.

Budhu M., Gobin R., 1996. Slope instability from ground-water seepage. Journal of Hydraulic Engineering 122: 415-417. DOI: 10.1061/ (ASCE)0733-9429(1996)122:7(415)).

Carter V., 1986. An overview of hydrologic concerns related to wetlands in the United States. Canadian Journal of Botany 64: 364-374.

Cole C.A., Brooks R.P., Wardrop D.H., 1997. Wetland hydrology as a function of hydrogeomorphic (HGM) subclass. Wetlands 17: 456467. DOI: 10.1007/BF03161511.

Cole C.A., Brooks R.P., Shaffer P.W., Kentula M.E., 2002. Comparison of hydrology of wetlands in Pennsylvania and Oregon (USA) as an 
indicator of transferability of hydrogeomorphic (HGM) functional models between regions. Environmental Management 30: 265-278. DOI: 10.1007/s00267-001-0055-6.

Cowardin L.M., Carter V., Golet F.C., LaRoe E.T., 1979. Classification of wetlands and deepwater habitats of the United States. U.S. Department of the Interior, Washington DC.

Curtis J.T., 1971. The vegetation of Wisconsin: an ordination of plant communities. University of Wisconsin Press, Madison.

Diggelen R., Middleton B., Bakker J., Grootjans A., Wassen M., 2006. Fens and floodplains of the temperate zone: Present status, threats, conservation and restoration. Applied Vegetation Science 9: 157-162. DOI: 10.1111/j.1654-109X.2006.tb00664.x.

Ebinger J.E., 1978. Vascular flora of hillside seeps in east-central Illinois. Transactions of the Illinois State Academy of Science 71: 109-114.

Ebinger J.E., Bacone J.A., 1980. Vegetation survey of hillside seeps at Turkey Run State Park. Proceedings of the Indiana Academy of Science 90: 390-394

Eilers L., Roosa D., 1994. The vascular plants of Iowa. University of Iowa Press, Iowa City.

Farina A., 2006. Principles and methods in landscape ecology: towards a science of the landscape. Springer, Dordrecht.

Gates F.C., 1912. A bog in central Illinois. Torreya 11: 205-211.

Goslee S.C., Brooks R.P., Cole C.A., 1997. Plants as indicators of wetland water source. Plant Ecology 131: 199-206. DOI: 10.1023/A:1009731904915.

Grootjans A.P., Adema E.B., Bleuten W., Joosten H., Madaras M., Janáková M., 2006. Hydrological landscape settings of base-rich fen mires and fen meadows: an overview. Applied Vegetation Science 9: 175-184. DOI: 10.1111/j.1654-109X.2006.tb00666.x.

Guertal W.R., Hall G.F., 1990. Relating soil color to soil water table levels. Ohio Journal of Science 90: 118-124.

Halsey L.A., Vitt D.H., Bauer I.E., 1998. Peatland initiation during the Holocene in continental western Canada. Climatic Change 40: 315342. DOI: $10.1023 / \mathrm{A}: 1005425124749$.

Herzberg R., Pearson J., 2001. The guide to Iowa's state preserves. University of Iowa Press, Iowa City.

Henry R.D., Scott A.R., Shildneck P., 1978. Additions to the distribution of Illinois vascular plants. Transactions of the Illinois Academy of Science 71: 51-61.

Henry R.D., Scott A.R., 1984. The wetland vascular flora of four seeps in McDonough County, Illinois. Phytologia 56: 1-15.

Hicks D.J., 2012. Vascular plant flora of two natural areas in Wabash County, Indiana. Castanea 77: 60-79. DOI: 10.2179/11-028.

Homoya M.A., 1984. A floristic survey of acid seep springs in Martin and Dubois Counties, Indiana. Proceedings of the Indiana Academy of Science 93: 323-331.

Iowa Department of Natural Resources. 2010. Digital Elevation Model (DEM) of the State of Iowa. Geological and Water Survey Bureau, Iowa City.

Iowa State University, 2013. Iowa Environmental Mesonet rainfall. Online: mesonet.agron.iastate.edu/rainfall - 02.08.2013.

James H.R., Fenton T.E., 1993. Water tables in paired artificially drained and undrained soil catenas in Iowa. Soil Science Society of America Journal 57: 774-781. DOI: 10.2136/sssaj1993.03615995005700030 $025 \mathrm{x}$

Kolka R.K., Thompson J.A., 2012. Wetland geomorphology, soils, and formative processes. In: D. Batzer (ed), Ecology of freshwater and estuarine wetlands. University of California Press, Berkeley: 7-42.

Kaul R.B., Kantak G.E., Churchill S.P., 1988. The Niobrara River Valley, a postglacial migration corridor and refugium of forest plants and animals in the grasslands of Central North America. The Botanical Review 54: 44-81. DOI: 10.1007/BF02858518.

Keddy P.A., 2010. Wetland ecology: principles and conservation. Cambridge University Press, New York.

Klijn F., Witte J-P.M., 1999. Eco-hydrology: Groundwater flow and site factors in plant ecology. Hydrogeology Journal 7: 65-77. DOI: $10.1007 / \mathrm{s} 100400050180$

Lauver C.L., Kindscher K., Faber-Langendoen D., Schneider R., 1999. A classification of the natural vegetation of Kansas. The Southwestern Naturalist 44: 421-443.
Leibowitz S.G., 2003. Isolated wetlands and their functions: An ecological perspective. Wetlands 23: 517-531. DOI: 10.1672/0277-5212(2003)023[0517:IWATFA]2.0.CO;2.

Mack J.J., 2009. Development issues in extending plant-based IBIs to forested wetlands in the Midwestern United States. Wetlands Ecology and Management 17: 117-130. DOI: 10.1007/s11273-008-9094-6.

Mausbach M.J., Richardson J.L., 1994. Biogeochemical processes in hydric soil formation. Current Topics in Wetland Biogeochemistry 1: 68-127.

McClain W.E., Phillippe L.R., Ebinger E., 2008. Seep community at White Oak Creek Woods Natural Area, Mason County, Illinois. Transactions of the Illinois State Academy of Science 101: 147-156.

Middelton B., Grootjans A.B., Jensen K., Olde Venterink H., Margóczi K., 2006. Fen management and research perspectives: An overview. In: R. Bobbink, B. Beltman, J.T.A. Verhoeven, D. F. Whigham (eds), Wetlands: Functioning, biodiversity conservation, and restoration. Spring-Verlag, Berlin: 247-268

Miner J.J., Ketterling D.B., 2003. Dynamics of peat accumulation and marl flat formation in a calcareous fen, Midwestern United States. Wetlands 23: 950-960. DOI: 10.1672/0277-5212(2003)023[0950:DOPAAM]2.0.CO;2.

Mitsch W.J., Gosselink J.G., 2000. The value of wetlands: Importance of scale and landscape setting. Ecological Economics 35: 25-33. DOI: 10.1016/S0921-8009(00)00165-8.

Mitsch W.J., Gosselink J.G., 2011. Wetlands, $4^{\text {th }}$ Edition. John Wiley \& Sons Inc., Hoboken.

Moran R.C., 1981. Prairie fens in northeastern Illinois: Floristic composition and disturbance. In: R.L. Stuckey, K.J. Reese (eds), Proceedings of the sixth North American prairie conference. Ohio State University, Columbus: 164-168.

Morley T.R., Calhoun A.J.K., 2009. Vegetation characteristics of forested hillside seeps in eastern Maine, USA. Journal of the Torrey Botanical Society 136: 520-531. DOI: 10.3159/08-RA-073.1.

Moore P.D., 1989. The ecology of peat-forming processes: A review. International Journal of Coal Geology 12: 89-103. DOI: 10.1016/01665162(89)90048-7.

Nekola J.C., 1994. The environment and vascular flora of northeastern Iowa fen communities. Rhodora 96: 121-169.

Nekola J.C., 2004. Vascular plant compositional gradients within and between Iowa fens. Journal of Vegetation Science 15: 771-780. DOI: 10.1111/j.1654-1103.2004.tb02320.x.

Nekola J.C., Lammers T.G., 1989. Vascular flora of Brayton-Horsley prairie: A remnant prairie and spring fen complex in eastern Iowa. Castanea 54: 238-254

O’Flaherty L.M., Ives J.D., Ozimek A.R., 1975. Sphagnum fimbriatum new to Illinois. The Bryologist 78: 455-458.

Orzell S.L., Kurz D.R., 1986. Floristic analysis of prairie fens in the southeastern Missouri Ozarks. In: G.K. Clambey, R.H. Pemble (eds), Proceedings of the ninth North American prairie conference. Tri-College University Centre for Environmental Studies, Moorhead: 50-58.

Parker H.M., Rayhill S.M., Ebinger J.E., 1970. Additions to the flora of Coles County, Illinois. Transactions of the Illinois Academy of Science 63: 375-378.

Parker H.M., Ebinger J.E., 1971. Ecological study of a hillside marsh in east-central Illinois. Transactions of the Illinois State Academy of Science 64: 362-369.

Phipps R., Speer J., 1958. A hillside marsh in east-central Illinois. Transactions of the Illinois State Academy of Science 51: 37-42.

Pearson J.A., Leoschke M.J., 1992. Floristic composition and conservation status of fens in Iowa. Journal of the Iowa Academy of Science 99: 41-52.

Prior J.C., 1991. Landforms of Iowa. University of Iowa Press, Iowa City.

Richardson J.L., Brinson M.M., 2001. Wetland soils and the hydrogeomorphic classification of wetlands. In: J.L. Richardson, M.J. Vepraskas (eds), Wetland soils: Genesis, hydrology, landscapes, and classification. CRC Press, Boca Raton: 209-227.

Rippey B., 2013. United States drought monitor - Iowa. Online: droughtmonitor.unl.edu - 02.08.2013.

Rosenblatt A.E., Gold A.J., Stolt M.H., Groffman P.M., Kellog D.Q., 2001. Identifying riparian sinks for watershed nitrate using soil 
surveys. Journal of Environmental Quality 30: 1596-1604. DOI: $10.2134 /$ jeq2001.3051596x.

Roulet N.T., 1990. Hydrology of a headwater basin wetland: Groundwater discharge and wetland maintenance. Hydrological Processes 4: 387-400. DOI: 10.1002/hyp.3360040408.

Saunders D.A., Hobbs R.J., Margules C.R., 1991. Biological consequences of ecosystem fragmentation: A review. Conservation Biology 5: 18-32. DOI: 10.1111/j.1523-1739.1991.tb00384.x.

Semeniuk C.A., Semeniuk V., 1995. A geomorphic approach to global classification for inland wetlands. Vegetatio 118: 103-124. DOI: 10.1007/BF00045193.

Shaffer P.W., Kentula M.E., Gwin S.E., 1999. Characterization of wetland hydrology using hydrogeomorphic classification. Wetlands 19: 490-504. DOI: 10.1007/BF03161688.

Skaggs R.W., Amatya D., Evans R.O., Parsons J.E., 1994. Characterization and evaluation of proposed hydrologic criteria for wetlands. Journal of Soil and Water Conservation 49:501-510.

Skalbeck J.D., Reed D.M., Hunt R.J., Lambert J.D., 2009. Relating groundwater to seasonal wetlands in southeastern Wisconsin, USA. Hydrogeology Journal 17: 215-228. DOI: 10.1007/s10040-008-0345-7.

Smith R.D., Ammann A., Bartoldus C., Brinson M.M., 1995. An approach for assessing wetland functions using hydrogeomorphic classification, reference wetlands, and functional indices. US Army Corps of Engineers, Washington DC.

Soil Survey Division Staff, 1993. Soil survey manual. United States Department of Agriculture Soil Conservation Service, Washington DC.

Soil Survey Staff, 2003. United States Department of Agriculture, Natural Resources Conservation Service, Soil Survey Geographic (SSURGO) Database - Muscatine County, Iowa. Online: websoilsurvey. nrcs.usda.gov - 24.10.2013.

Soil Survey Staff, 2010. Keys to soil taxonomy, 11th ed. United States Department of Agriculture Natural Resources Conservation Service, Washington DC.

Soil Survey Staff, 2013. United States Department of Agriculture, Natural Resources Conservation Service, Official Soil Series Descriptions. Online: soils.usda.gov/technical/classification/osd/index.html $-24.10 .2013$

Stein E.D., Mattson M., Fetscher A.E., Halama K.J., 2004. Influence of geologic setting on slope wetland hydrodynamics. Wetlands 24 : 244 260. DOI: 10.1672/0277-5212(2004)024[0244:IOGSOS]2.0.CO;2.

Tiner R.W., 2003. Geographically isolated wetlands of the united states. Wetlands 23: 494-516. DOI: 10.1672/0277-5212(2003)023[0494:GIWOTU]2.0.CO;2.

Thompson C.A., Bettis E.A., Baker R.G., 1992. Geology of Iowa fens. Journal of the Iowa Academy of Science 99: 53-59.
Thompson C.A., Bettis E.A., 1994. Age and developmental history of Iowa fens. Journal of the Iowa Academy of Science 101: 73-77.

Thompson Y., Sandefur B.C., Miller J.O., Karathanasis A.D., 2007. Hydrologic and edaphic characteristics of three mountain wetlands in southeastern Kentucky, USA. Wetlands 27: 174-188. DOI: 10.1672/0277-5212(2007)27[174:HAECOT]2.0.CO;2.

USDA-NRCS, 2010. Field indicators of hydric soils in the United States, a guide for identifying and delineating hydric soils, version 7.0. United States Department of Agriculture Natural Resources Conservation Service, Washington DC.

Van Sickle J., 2001. GPS for land surveyors, 2nd edition. Taylor \& Francis, New York

Weakley A.S., Schafale M.P., 1994. Non-alluvial wetlands of the Southern Blue Ridge - Diversity in a threatened ecosystem. Water, Air and Soil Pollution 77: 359-383. DOI: 10.1007/BF00478428.

Wheeler B.D., Proctor M.C.F., 2000. Ecological gradients, subdivisions and terminology of north-west European mires. Journal of Ecology 88: 187-203. DOI: 10.1046/j.1365-2745.2000.00455.x.

Whigham D.F., Jordan T.E., 2003. Isolated wetlands and water quality. Wetlands 23: 541-549. DOI: 10.1672/0277-5212(2003)023[0541:IWAWQ]2.0.CO;2.

Winter T.C., 1988. A conceptual framework for assessing cumulative impacts on the hydrology of nontidal wetlands. Environmental Management 12: 605-620. DOI: 10.1007/BF01867539.

Winter T.C., 1999. Relation of streams, lakes, and wetlands to groundwater flow systems. Hydrogeology Journal 7: 28-45. DOI: 10.1007/ s100400050178.

Winter T.C., 2001. The concept of hydrologic landscapes. Journal of the American Water Resources Association 37: 335-349. DOI: 10.1111/ j.1752-1688.2001.tb00973.x.

Zedler J.B., Kercher S., 2005. Wetland resources: Status, trends, ecosystem services, and restorability. Annual Review of Environment and Resources 30: 39-74. DOI: 10.1146/annurev.energy.30.050504.144248.

Zhang Y-K., Schilling K.E., 2006. Effects of land cover on water table, soil moisture, evapotranspiration, and groundwater recharge: A field observation and analysis. Journal of Hydrology 319: 328-338. DOI: 10.1016/j.jhydrol.2005.06.044.

Zimmerman J.H., 1976. Notes on Wisconsin prairie fens - Characteristics and relationships. In: D.C. Glenn-Lewin, R.Q. Landers (eds), Proceedings of the fifth Midwest prairie conference. Iowa State University, Ames: 191

Zobeck T.M., Ritchie A., 1984. Relation of water table depth and soil morphology in two clay-rich soils of northwestern Ohio. Ohio Journal of Science 84: 228-236. 